\title{
The Impact of Packaging on Customer's Buying Decision
}

\author{
Prianjana Roy ${ }^{1} \quad$ Md Nazmus Sadekin $^{2 *} \quad$ Md Mazadul Hoque ${ }^{3} \quad$ Mohammad Shahjahan Siddiqui $^{4}$ \\ 1,2 Department of Economics, Mawlana Bhashani Science and Technology University, Santosh, Tangail-1902, \\ Bangladesh \\ 3 Senior Executive Officer, Social Islami Bank Limited, Bangladesh \\ 4 Legal Economist and Adjunct Faculty, Daffodil International University, Dhaka, Bangladesh
}

\begin{abstract}
The aim of our study is to show the impact of packaging and on customer's buying decision. By observing various literature, I construct a proposed model and to justify the model accuracy is used PLS-SEM (Partial Least Squares - Structural Equation Models) SmartPLS 3.2.8. The outcome of my study revels, there is a very significant relationship between on consumer's buying decision. Now a day's consumers are very conscious and it is very critical to influence their buying decision. Packaging has that ability to affect the buying decision. Packaging also has a very significant impact on consumer's buying decision.
\end{abstract}

Keywords: Customers' Buying Decision, Innovation, Packaging, Package Color, Package Design, Package Materials, Printed Information, Typography.

DOI: $10.7176 / \mathrm{DCS} / 11-5-04$

Publication date:May $31^{\text {st }} 2021$

\section{Introduction}

\subsection{Background of the Study}

Now-a-days product manufacturing companies try to increase their sales in various ways, of them packaging is mentionable. Manufacturing companies try to attract customers by athletics packaging. According to (B. J. B. f. j. Rundh, 2005) package offers consumer's mindfulness towards a specific brand, builds its image, and animates consumer's insights about product. Bundling passes on particular value to products. Packaging assumes an essential job in drawing in buyers towards any product (Silayoi \& Speece, 2007). The packaging is likewise utilized as the limited time device for the organizations and it incorporates color, structures, material, and different qualities. Packaging attracts potential customers consciously or subconsciously whether to buy a product or not. More than $70 \%$ of buying decisions are taken at the shelf, as product's packaging draws customer's attention first. A good package design can influence customers to buy products strongly. On the other hand, a bad package design can influence the brand image negatively. A good package design with high quality even though company has to spend a good amount of money can direct the customers to purchase the product. The packaging is the general package offer by the organization to its customers and animates the drive buying behavior. Packaging draws in purchasers and expands its deal. It likewise decreases the marketing and advertisement cost of the product. According to (Raheem, Vishnu, \& Ahmed, 2014) package color, package design, package material and innovation may drive customer to purchase any product. Another thing that in printed information in product that also drives customers to purchase any product. There is no mention of printed information in that study. Printed information in package also helps customer to make a purchase. (Silayoi \& Speece, 2004). Bad and unclear typography may not attract customers to make a purchase. (Abdullah, Kalam, Akterujjaman, \& Volume, 2013). The packaging is a sort of advertising device which advances the product in the market. Packaging acts as the language of item which gives the essential qualities and significant information about the item. At the end of the day, we can say that packaging is the principal source which gives a remarkable character to the item and demonstrates the predominance of an item in a market. The packaging is a significant segment of the marketing framework which assumes a vital role in promotion, increasing sales, and brand image. For example, before 2013 students of primary school and high school in Bangladesh preferred cake that had no specific packet and sold openly for 5 BDT. In 2013 PRAN-RFL Group introduced Tiffin Cake with a colorful and good quality packet also for 5 BDT and created a good impression to potential customers. Then it gradually replaced openly selling cake and the customers of openly selling cake dramatically switched to the Tiffin Cake only for its packaging. It might be said that packaging plays a vital role on purchasing a product.

\subsection{Statement of Problem}

In December 2008, Beb Nath Sharma studded new purchaser products branding, packaging and marking in Nepal. His examined centers around the current act of branding packaging and marking of new products in the assembling units in customer product. the investigation methodology through which the information is gathered through poll is spellbinding, the overview was completed with various customer and new products like bread roll, cleanser, cigarettes, noodles, and so forth the examination farther show that the new buyer thing naming and packaging status in industrial unit. (Shah, Ahmed, \& Ahmad, 2013). Packaging is censured commonly considering its ecological effect on exhausting regular assets; specific sort of groups are wellbeing risks; and 
there is issue of expulsion of packs; a couple of packs are tricky; others are costly. (Ghosh, 2016).

This study may drive businesspersons and companies to give an extra attention to these factors of packaging and improve them to attract more customers than their targeted customers. Most of the customers judge any product according to the package design. Graphics on packaging make a brand one of a kind, save its singularity, assists in accentuating the name of the brand and stands apart on the shelf. (Smith \& Walker, 2004). Poor graphic design and color combination fails to attract the customers. Products from the foreign country may use their own native language on product's package. Often it might not be understandable by the customers. Nevertheless, text on the package should be very clear to the customers. Now-a-days customers have a tendency of reusing. If package should be in such way which customers can reuse the package, it will add extra value to the product. Moreover, manufacturing date, expiry date, price, components should be mentioned in package. If they are not mentioned customers lose their will to purchase any products. Lastly the materials of packaging should be protective. Poor packaging materials may not protect any products from damages. Moreover, materials in like manner impact the obvious idea of a thing, which infers buyer experiences as for explicit materials could change the evident idea of a thing. Some packaging materials are to be made as it were, with the target that it could bear the temperature under nothing or high temperatures in microwave dependent upon the thing functionalities and the necessities of a customer. (Oaya, Newman, \& Ezie, 2017) Customers' buying decision may depends on the extra protective packaging.

A great deal in the business have left on one or many tactics to capture the portion of the market for their products. While trying to get more clients to buy their products, associations have busy with different improvements to make their product rival that of competitors, the packaging structure is one way to deal with get customer attention. (Oaya et al., 2017). According to (B. Rundh, 2005) Package stands apart for customer to explicit brands, redesigns its image, and effects purchaser's experiences about products, as such packaging a particular product subject to your buyer needs, the producer can use naming or picture depiction to animate the interest of the shopper to purchase that product, when the customer is moved by the image or name used to package the product the person being referred to needs or makes a purchase for that product that is required.

\subsection{Research Questions}

1.How to find out the effect of packaging on the customer's buying decision?

2.How to check the effect of packaging elements on the buying behavior of customers?

3.How to measure the relative impact of each packaging elements on the customers?

\subsection{Research Contribution}

Different companies or brand use different package design, package color and materials to influence consumers. This research on packaging will help companies/brand/business man to have more customers who chooses product by package design, package color, typography, innovation, printed information and also package materials. Every term has a contribution to consumers buying decision.

When buying something at first customer look at the design of the product. If the design failed to attract then customer doesn't buy that product. The package design is the important fact that is explained broadly in this research paper that will help the businessman/companies to attract the customers.

When a consumer buys a product the package color catches the attention. Some product package should be mild, and some product color should be colorful but maximum people avoid too much extreme colorful packaging. This topic is not of less important for the customers buying decision.

The products of multinational companies are used all over the companies. Some products are originated from UK some products are originated from India; some products are originated from Bangladesh. The products of these countries are used all over the world but the typography should be convenient for all the people of the world who doesn't know French would not buy that product which is explained in French research on typography of a package has a great contribution.

Customers are generally attracted to the innovation sustainable packages are more preferable to any customer than any other packaging. If customer get a free box with an ice cream with 100 taka and he/she also can have an ice cream with paper wrapped at 50 then the customer will prefer the box ice cream. Because he/she can use that box in other field after eating ice cream.

Before purchasing any product specially food product/skin care product customer must check printed information that means manufacture date and expiry date. If that information is not mentioned clearly then customer don't buy that product.

Package materials means by which materials the package is produced. Most of the customers want sustainable package that is reusable. Hard paper packaging, small container packaging is most preferable than one-time packaging. 


\section{Review of Literature and Development of Hypothesis \\ 2.1. Review of Literature}

Searching previous researcher's observation on packaging. Unfortunately, it is rarely found research work on the impact of packaging on customer's buying decision. Consumer buying decision is attributed by packaging which is opined by many scholars.

Packaging is the cubicle of a product - consolidating the actual appearance of the compartment including the plan, shading, shape, marking and material used (Arens, 2002). According to (William, 1993) Packaging perhaps characterized as the overall gathering of exercises in product arranging which helps in esteem planning and assembling the holder or covering of a product. Various supervisors think the bundle's main role is to engage buy. For a few, consumer bundled products, the bundle continues advancing the brand and affecting consumers long after it is bought. Suggested by (De Faultrier, Towers, \& Services, 2011) Packaging includes both marketing and logistics contemplations and incorporates the packaging marketing blend, the strategic contemplations. Packaging right now is seen as a fundamental piece of our front-line way of life and the way in which business is figured out.

Packaging is the encasing of an actual thing, consistently a thing that will be offered accessible to be bought. After it is home it can affect how an individual sees its taste and worth, how much an individual uses consistently, and surprisingly how the person being referred to utilizes it. essential limit of packaging is to guarantee the thing against possible mischief while moving, taking care of, selling and mishandling items.(Gonzalez, Thornsbury, \& Twede, 2007) Here are four of his fascinating findings. Our sensation of taste and contact is absolutely suggestible, and what we see on a package can lead customers to taste what they figure they will taste.

A respectable packaging shading assists with perceiving thing to the consumers. Packaging is utilized for even more effectively transport and for affirmation and fenced in area of the thing. Various organizations endeavor to make squeezing novel and in a way that it will fulfill consumers. The correct words and pictures on a bundle can influence these assumptions. Packaging can affect esteem. One examination found that people acknowledge tall, slight bundles hold all the more a thing than short, wide bundles. Singular tendencies become progressively baffling and grouped, packaging transforms into the critical techniques for thing branding, packaging in like manner gives the really enduring impression of thing brand to the customer (Hill \& Tilley, 2002). Packaging can affect utilization. Investigations of 48 distinct sorts of food varieties and individual consideration products have shown that individuals pour and burn-through 18 to $32 \%$ even more a product as the size of the compartment copies. (Keller, Parameswaran, \& Jacob, 2011) Packaging can impact how an individual uses a thing one procedure to amass the use of making products has been to demand that people utilize the brand in new conditions, like soup for breakfast, or for new uses, for example, warming soft drink as a cooler deodorizer. Packaging should be clear with the thing's advancing, assessing and scattering. Affiliations all things considered a few explicit package plans for something different. To pick the best package, affiliations reliably test various plans to find the one that stands up best under customary use, least referencing for merchants to regulate and gets the best purchaser's response. Package configuration is possibly the essential pieces of thing system. About $70 \%$ of all purchase choices of product are made at the support purchase. This can be considered typical that the genuine package is the fundamental showing correspondence the consumer may get while investigating the thing. Style package plans are wanted to attract the objective market and fortify consumer purchase conduct. (Mutsikiwa \& Marumbwa, 2013)

A drawing in and effective packaging design, appropriate design, images and beautifications is progressively fruitful in pulling in customers. For the present circumstance package designs may enliven customers to again and again purchase a product. (Asadollahi \& Givee, 2011). The history of the utilization of package materials is venerable. "Early packaging materials to be utilized incorporate the leaves, creature skin, ceramics vessels, and woven sacks. Be that as it may, these have advanced to prepared materials, for example, plastic bottles and papers, wooden vessels, corrugated boxes, metal containers and others" (Twede, 2005). "Product safety is a hidden element of saw product quality, is made out of such countless parts that it would skirt on ambiguity to think of it as just when all is said in done terms. In fact, a product can be seen as being need fulfilling, henceforth satisfying piece of the idea of "product quality", for instance, a nourishment product might be exceptionally heavenly (for the most part acknowledged as establishing quality), however might be thought to contain fake added substances that are hurtful to the consumer" (Tse, 1999)"In order to survive in high growth, competitive markets, technology becomes very important for developing packaging, materials" (Silayoi \& Speece, 2004).

Different interviewees in like way felt that it was getting crucial for base on packaging materials, which impact comfort correspondingly as the genuine thing. The tones can build up a huge and strong association and picture about the product or brand. In the packaging of products, publicists use tones to get the customers ${ }^{\text {ce }}$ thought which in this manner makes either a negative or great tendency about the particular product/brand. (Mutsikiwa \& Marumbwa, 2013). The shades of the packaging is the most significant at 1\%. (Ahmad, Billoo, \& 
Lakhan, 2012). Package colors have the capability to evoke feelings, emotions and behaviors in different consumers (Mutsikiwa \& Marumbwa, 2013). (Asadollahi \& Givee, 2011) recommended that the package tones impart, reflect and show some noteworthy features and irrelevant characteristics of the brand. Customers take in tints relationship from current brands in the publicize, which lead them to slant toward explicit shades for various thing classes. Using concealing as a sign on packaging can be a possibly strong affiliation, especially when it is exceptional to a particular brand. In any case, people in different social orders are introduced to different concealing affiliation and make concealing tendencies reliant on their own lifestyle affiliations (Rettie, Brewer, \& management, 2000).

Package guidelines go about manual engraved through a message on the best way to enhance the utilization obliged by a product. Customers examine for and evaluate information about the usage product, date of expire, materials, weight, volume, and disposal before buying. (Kupiec \& Revell, 2001) Customers to be informed and affected purchase decision through package instructions. (Kupiec \& Revell, 2001). With rising degrees of consumer instruction and mindfulness, it is inescapable for advertisers to painstakingly design their data perceivability on the packages of the products to forestall disarray and fairly persuade customers at the point-ofpurchase. (Mutsikiwa \& Marumbwa, 2013).

\subsection{Development of Hypothesis}

Never barely care about the significance of buying publicists oftentimes check brand observations of customers and dismissal of the package. Notwithstanding, the way that consumer from the way wherein that consumers respond to unbranded products that packaging expects a colossal part in invigorating customer acknowledgments. Packaging facilitates, the way wherein a product is experienced by customer. Be that as it may, we put little energy investigating the relationship among packaging and the prompt insight of the product "The best methods for standing out to a product is by concentrating consideration on product brand using a proper color, size, language, and picture while expanding product availability" (Scholssberg, 2008). According to (Lamb, Joseph F. Hair, \& McDaniel, 2004) Packages use design, shadings and materials to attempt to impact consumer's insights and purchasing behavior just as development in packaging has additionally the impact in customers' purchasing choice. (Ghosh, 2016; Raheem et al., 2014). Typography in package affects customers buying decision. (Silayoi \& Speece, 2004) and also it is assumed that printed information such as manufacturing and expiry date, components, weight about the product often influence customer's buying decision.

H1: Package Design has a positive impact on buying decision of customer

H2: Package Color has a positive impact on buying decision of customer

H3: Typography in package has a positive impact on buying decision of customer

H4: Innovation in packaging has a positive impact on buying decision of customer

H5: Printed Information has a positive impact on buying decision of customer

H6: Package Material has a positive impact on buying decision of customer

\section{Methodology}

\subsection{Model}

It is the study of buying decision that is impacted by the packaging. Here in this proposed model packaging is independent variable and buying decision is considered as dependent variable. There are also several factors underlying on independent variables shown on the proposed model. This is an exploratory study which is intended to analyze how packaging influences customer's buying decision of. The relationship between dependent and independent variables based on customer point of view. In this model the independent variable which is packaging and consists of six factors- package design, package color, typography, innovation, materials, printed information. These six factors have a direct influence on packaging. Premium package with good combination of package colors and materials as well as unambiguous manufacturing and expiry date have an attribution on consumer buying decisions. The assumptions are based on various previous study that consumers, their mind and their buying decisions are very critical to understand and they depend on some fickles. 


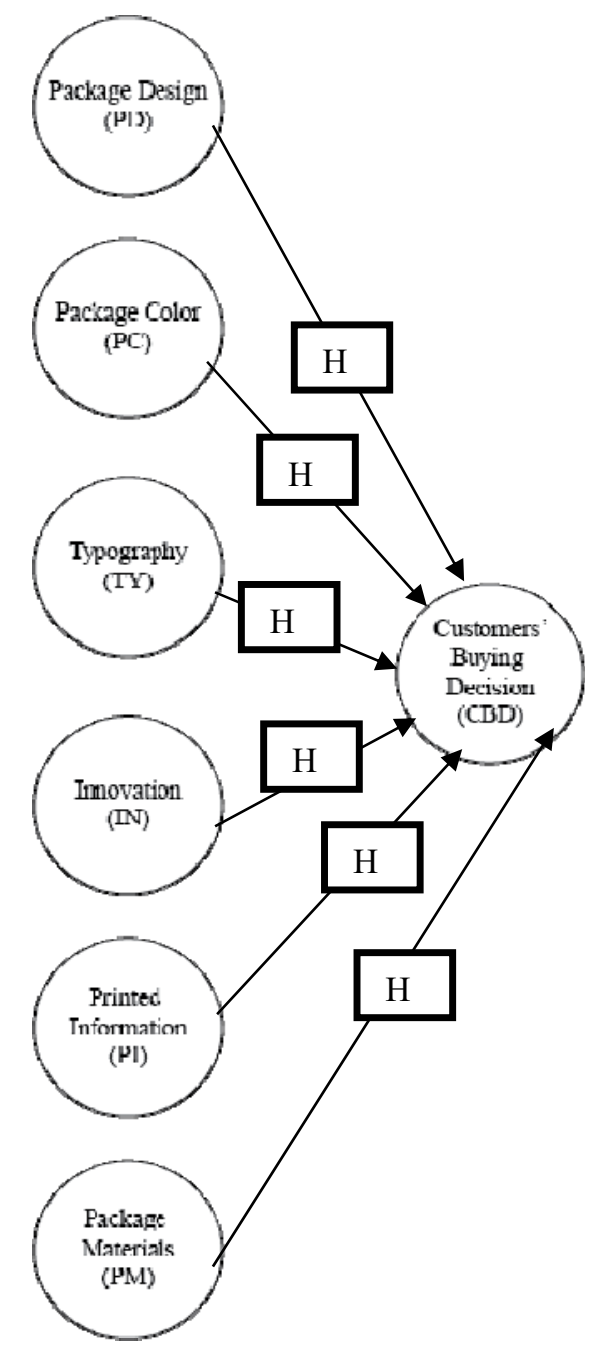

Figure 1: Proposed Model

\begin{tabular}{|l|l|}
\hline \multicolumn{2}{|c|}{ Table 1: Research Variables } \\
\hline Package Design & An aesthetics package design influence consumer buying intention. \\
\hline Package Color & $\begin{array}{l}\text { Attractive package color that matches customer's personality and hit customer's emotion, it } \\
\text { influences customer buying decision. }\end{array}$ \\
\hline Typography & The differing fonts, dispersing, and measuring of the printed data texted on the package. \\
\hline Innovation & Adding value to the product by preparing such a package which can be reused. \\
\hline $\begin{array}{l}\text { Printed } \\
\text { Information }\end{array}$ & $\begin{array}{l}\text { Printed information such as manufacturing and expiry date, components, weight about the } \\
\text { product often influence customer's buying decision. }\end{array}$ \\
\hline $\begin{array}{l}\text { Package } \\
\text { Materials }\end{array}$ & Considering product's package materials consumers often make buying decision. \\
\hline $\begin{array}{l}\text { Customers' } \\
\text { Buying } \\
\text { Decision }\end{array}$ & $\begin{array}{l}\text { Packaging plays a vital role while customers making a buying decision. Customer's } \\
\text { perception towards a package of a product as well as their packaging affects their buying } \\
\text { decision. }\end{array}$ \\
\hline
\end{tabular}

\subsection{Strategy}

In this study, To collect data and I used google form questionnaire. My research paper is based on primary data. My questionnaire consisted of 3 sections and 6 sub sections. The first part of these section is Section 1 which contains demographic information. I set the questionnaire section-2 with six sub sections, I include package design, package color, typography, innovation, printed information, package materials consecutively. Last section is about customers' buying decision. I have organized my questionnaire with 50 questions along with 5 point likert scale. I have collected data from male and female both and also from the students of different universities because I want to know how their buying decision influenced by packaging. I distributed 
questionnaires through online media like Facebook, Email, WhatsApp to reach the respondents. The respondents are from various locations of Bangladesh. I distributed 300 questionnaires and out of the 300 distributed questionnaires I was succeed to collect 253 responses and the response rate is $84 \%$. I clarified any of topic or content in my questionnaire to make it simple to the participants. I believe that $84 \%$ responses are sufficient for understanding the impact of packaging on customer's purchase decision. (Osman, Sentosa, \& Studies, 2013) To examine the gathered data and to analyze the relationships among variables, a tool named SmartsPLS 3.2.8 was used and tassess among the model.

\section{Data Analysis and Findings}

Figure 2 exhibits the entire outcomes utilizing Bootstrapping technique for the hypothesized model.

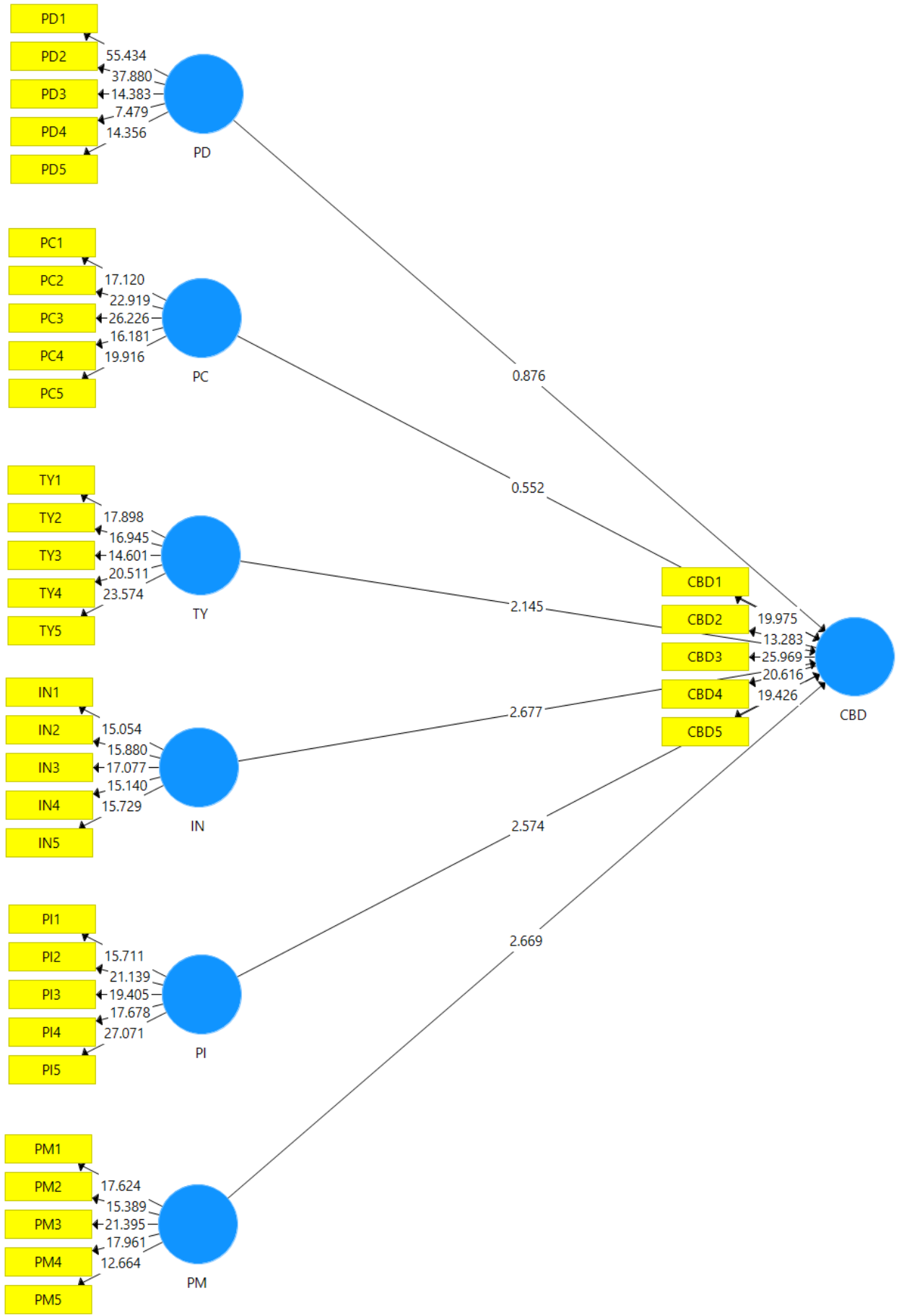

Figure 2 
Figure 3 exhibits the entire outcomes utilizing PLS Algorithm technique for the hypothesized model.

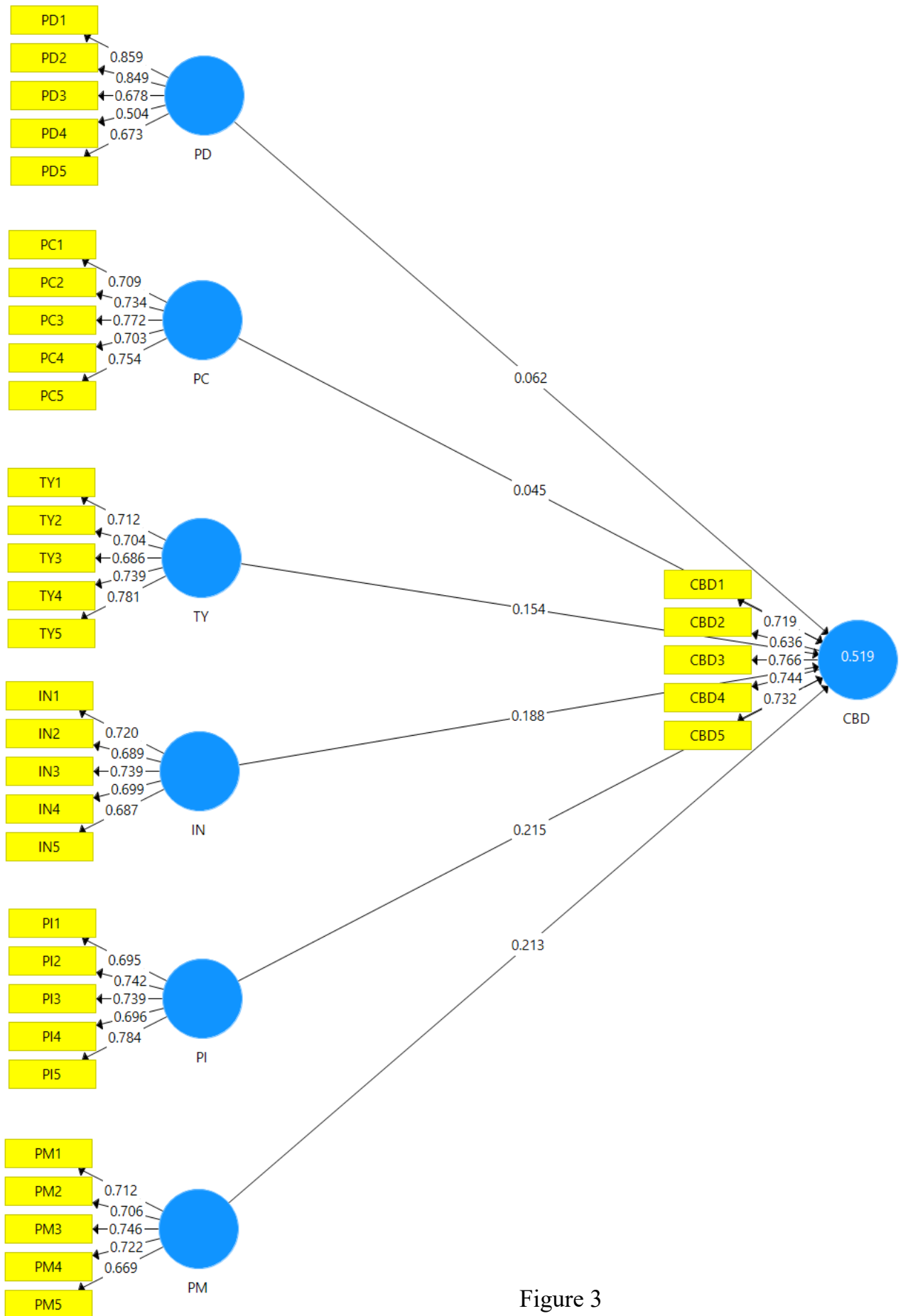

When there are significant path coefficients, adequate R2 values, and great construct reliability, a solid model fit in PLS is existent (Gefen, Straub, \& Boudreau, 2000). The assessment of reliability, composite reliability and average variance extracted (AVE) is appeared in Table 2 and these are the two significant estimations used in this monograph. According to (Chin, 1998), Composite reliability doesn't accept that all pointers are also weighted that recommends that composite reliability may be more suitable to evaluate reliability. Composite reliability is should be higher than 0.7 (Barclay, Higgins, \& Thompson, 1995; Fornell \& Bookstein, 1982). The other measurement, average variance extracted shows the change sum that a form limits from its pointers relative with the entirety as a result of measurement error (Chin, 1998). For average variance extracted 0.5 is the acceptable minimum critical value. (Marsh, Hau, \& Wen, 2004). Table 2 shows composite 
reliability and values of average variance extracted.

To quantify interior consistency for reliability Cronbach's alpha is utilized. It is viewed as a proportion of scale reliability. Cronbach's alpha -0.90 or more is the best, above is better and 0.70 or more is acceptable. These values of greatest factors are bigger than 0.70 in table 2 . As they are over the suggested edge, these values are viewed as acceptable and dependable when the value is 0.70 (Sekaran \& Bougie, 2010).

\begin{tabular}{|c|c|c|c|}
\hline \multicolumn{3}{|c|}{ Table 2: Construct Reliability and Validity } \\
\hline & Cronbach's Alpha & Composite Reliability & Average Variance Extracted (AVE) \\
\hline CBD & 0.768 & 0.844 & 0.520 \\
\hline IN & 0.753 & 0.833 & 0.500 \\
\hline PC & 0.787 & 0.854 & 0.540 \\
\hline PD & 0.772 & 0.842 & 0.525 \\
\hline PI & 0.783 & 0.852 & 0.536 \\
\hline PM & 0.757 & 0.837 & 0.506 \\
\hline TY & 0.774 & 0.847 & 0.526 \\
\hline
\end{tabular}

For discriminant validity test, each factor was more noteworthy than its relationships with different components in the square base of the average variance extracted (Fornell \& Larcker, 1981). Discriminant validity involves the wellness of individual factor interfaces with its speculated construct conversely with others (Osman \& Sentosa, 2013). The level of discriminant validity utilizing Fornell-Larcker Criteria that fulfills the previously noted standards and discriminant validity as significant is displayed in Table 3.

\begin{tabular}{|c|c|c|c|c|c|c|c|}
\hline \multicolumn{7}{|c|}{ Table 3: Discriminant Validity -Fornell-Larcker Criterion } \\
\hline & CBD & IN & PC & PD & PI & PM & TY \\
\hline CBD & 0.721 & & & & & & \\
\hline IN & 0.581 & 0.707 & & & & & \\
\hline PC & 0.566 & 0.550 & 0.735 & & & & \\
\hline PD & 0.564 & 0.657 & 0.601 & 0.725 & & & \\
\hline PI & 0.627 & 0.577 & 0.719 & 0.608 & 0.732 & & \\
\hline PM & 0.595 & 0.527 & 0.622 & 0.622 & 0.637 & 0.712 & \\
\hline TY & 0.574 & 0.593 & 0.607 & 0.573 & 0.635 & 0.516 & 0.725 \\
\hline
\end{tabular}

The eagerness of the data is fitted regression line for the measurement, $\mathrm{R}$ square and adjusted $\mathrm{R}$ Square are used. R square criteria reflects the consistency and strength of a model characteristics and that is a basic determinant of the model (Chin, 1998). According to (Alrousan \& Abuamoud, 2013) "R square is the proportion of variation in the needy variable clarified by the regression model. The assessments of $\mathrm{R}$ square range from 0 to 1. A couple of characteristics show that the model doesn't fit the information well. R Square is used to help determine which model is fit." Adjusted R square endeavors to correct R square to accurately reflect the integrity of wellbeing of the model in the population (Alrousan \& Abuamoud, 2013). The results of this analysis are shown in table 4 which depict model as satisfactory and fitted.

\begin{tabular}{|c|c|c|}
\hline \multicolumn{3}{|c|}{ Table 4: R Square and Adjusted Square } \\
\hline & R Square & R Square Adjusted \\
\hline CBD & 0.519 & 0.507 \\
\hline
\end{tabular}

Convergent validity is the ability of a scale to load all together construct and is assessed by taking a gander at each stacking for every square of indicators (Osman et al., 2013). Outer loading's value ought to be higher than 0.7 and it reveals that the indicators share more variance with their respective latent variable (LV) than with error variance. A lower breaking point of 0.50 may be acceptable (Chin, 1998). In my analysis the value of convergent validity utilizing cross loading matrix is appeared in Table 5 which satisfies the previously mentioned criteria. 


\begin{tabular}{|c|c|c|c|c|c|c|c|}
\hline \multicolumn{8}{|c|}{ Table 5: Outer Loadings-Cross Loading Matrix } \\
\hline & CBD & IN & PC & PD & PI & PM & TY \\
\hline CBD1 & 0.719 & & & & & & \\
\hline CBD2 & 0.636 & & & & & & \\
\hline CBD3 & 0.766 & & & & & & \\
\hline CBD4 & 0.744 & & & & & & \\
\hline CBD5 & 0.732 & & & & & & \\
\hline IN1 & & 0.720 & & & & & \\
\hline IN2 & & 0.689 & & & & & \\
\hline IN3 & & 0.739 & & & & & \\
\hline IN4 & & 0.699 & & & & & \\
\hline IN5 & & 0.687 & & & & & \\
\hline PC1 & & & 0.709 & & & & \\
\hline PC2 & & & 0.734 & & & & \\
\hline PC3 & & & 0.772 & & & & \\
\hline PC4 & & & 0.703 & & & & \\
\hline PC5 & & & 0.754 & & & & \\
\hline PD1 & & & & 0.859 & & & \\
\hline PD2 & & & & 0.849 & & & \\
\hline PD3 & & & & 0.678 & & & \\
\hline PD4 & & & & 0.504 & & & \\
\hline PD5 & & & & 0.673 & & & \\
\hline PI1 & & & & & 0.695 & & \\
\hline PI2 & & & & & 0.742 & & \\
\hline PI3 & & & & & 0.739 & & \\
\hline PI4 & & & & & 0.696 & & \\
\hline PI5 & & & & & 0.784 & & \\
\hline PM1 & & & & & & 0.712 & \\
\hline PM2 & & & & & & 0.706 & \\
\hline PM3 & & & & & & 0.746 & \\
\hline PM4 & & & & & & 0.722 & \\
\hline PM5 & & & & & & 0.669 & \\
\hline TY1 & & & & & & & 0.712 \\
\hline TY2 & & & & & & & 0.704 \\
\hline TY3 & & & & & & & 0.686 \\
\hline TY4 & & & & & & & 0.739 \\
\hline TY5 & & & & & & & 0.781 \\
\hline
\end{tabular}

Bootstrapping procedure of PLS-SEM is used to calculate the value of T-statistics, if these values support the hypotheses or not for testing research hypotheses. The level of certainty for testing hypotheses to be 0.95 . All the hypotheses for which the significance number is within the range of 1.96 to 1.96 are acknowledged. Table 6 shows that the hypotheses concerning the effect of packaging on customer's purchasing choice. In this way, from the table 6 apparently two hypotheses are rejected and four hypotheses are accepted as significance level is $5 \%$ and path coefficient with T-statistics is greater than 1.96.

Here, from the Table 6 of final result regarding hypotheses supported and not supported condition, we can see that people from different professions with different their own perspective has provided their opinion and based on these the results reveals that Package Color has no impact on Customer Buying Decision (H2) as the value of T-statistics of this hypothesis is 0.552 which is lower than the acceptance criteria (1.96) and 0.581 is the $\mathrm{P}$ value which is greater than the significance level $(0.05)$. This is the reason for which hypothesis is not supported. Then, H1 is also not accepted because value of T-statistics $0.876<1.96$ and $\mathrm{P}$ value $0.382>0.05$ and Package Design has no impact on Customer Buying Decision as the remaining hypotheses are accepted because they have fulfilled the acceptance criteria. 


\begin{tabular}{|c|c|c|c|c|c|c|}
\hline \multicolumn{7}{|c|}{ Table 6: Path Coefficients-Mean, STDEV, T-Values, P-Values } \\
\hline & $\begin{array}{c}\text { Original } \\
\text { Sample (O) }\end{array}$ & $\begin{array}{c}\text { Sample } \\
\text { Mean (M) }\end{array}$ & $\begin{array}{c}\text { Standard Deviation } \\
(\text { STDEV) }\end{array}$ & $\begin{array}{c}\text { T Statistics } \\
(\mid \mathbf{O} / \text { STEV|) }\end{array}$ & P Values & $\begin{array}{c}\text { Result of } \\
\text { Hypothesis }\end{array}$ \\
\hline $\begin{array}{c}\text { IN -> } \\
\text { CBD }\end{array}$ & 0.188 & 0.192 & 0.070 & 2.677 & $\mathbf{0 . 0 0 8}$ & Supported \\
\hline $\begin{array}{c}\text { PC - } \\
\text { CBD }\end{array}$ & 0.045 & 0.052 & 0.081 & 0.552 & $\mathbf{0 . 5 8 1}$ & Not Supported \\
\hline $\begin{array}{c}\text { PD -> } \\
\text { CBD }\end{array}$ & 0.062 & 0.063 & 0.070 & 0.876 & $\mathbf{0 . 3 8 2}$ & Not Supported \\
\hline $\begin{array}{c}\text { PI - } \\
\text { CBD }\end{array}$ & 0.215 & 0.215 & 0.084 & 2.574 & $\mathbf{0 . 0 1 0}$ & Supported \\
\hline $\begin{array}{c}\text { PM -> } \\
\text { CBD }\end{array}$ & 0.213 & 0.205 & 0.080 & 2.669 & $\mathbf{0 . 0 0 8}$ & Supported \\
\hline $\begin{array}{c}\text { TY -> } \\
\text { CBD }\end{array}$ & 0.154 & 0.153 & 0.072 & 2.145 & $\mathbf{0 . 0 3 2}$ & Supported \\
\hline
\end{tabular}

Typography, Innovation, Printed Information and Package Material have positive relation with customer's buying decision. On the other hand, Package Design and Package color have no influence on customer's buying decision. Relation among the variables are as follows:

1. There is no relationship between Package Design and Customers' Buying Decision.

2. There is no relationship between Package Color and Customers' Buying Decision.

3. Typography has a positive relationship with Customers' Buying Decision.

4. Innovation has a positive relationship with Customer's Buying Decision.

5. Printed Information has a positive relationship with Customers' Buying Decision.

6. Package Material has a positive relationship with Customers' Buying Decision.

\section{Conclusion}

The aim of this study is to examine the relationship between packaging as well as it's combined impact on customer buying decision. Studying various research papers and completing my monograph, I identified significant impact between packaging and customer's buying decision.

This study may assist those personnel who are involved in marketing, sales and promotion sectors. This study will help them to understand the impact of packaging on consumer buying decision as well as the importance of packaging and knowledge of customer behavioral intention on consumer buying decision. Consumer's buying decision is very complicated and influenced by various factors of packaging and it is mentioned in previous studies. To show the relationship between the variables, I constructed a proposed research model after studying the papers from various researchers. To justify the exactness of my model. For this purpose, I have directed experimental analysis, PLS techniques are applied for dissecting data. The findings of research suggest that customer's buying decision might be altered or impacted by developing the packaging and understanding the buying decision of the customers. Nevertheless, the professionals should have detailed knowledge to impact their customer's buying decision.

\section{Limitations}

Through this study several results are discovered however few limitations are alluded. This study reveals that There is a positive impact of packaging on customer's buying decision is revealed by this study. Notwithstanding, there are some other factors that could also influence the dependent and independent variables but the factors are not analyzed. Thus, relative factors of packaging and customer's buying decision might be used in future study. Another constraint of the study was the respondents whose responses make this monograph complete in this study were limited to a certain extent. The gathered data or the whole population may not represent the entire customer. Future studies of this related field should incorporate diversified samples to ensure pertinence of the research findings to other various settings.

\section{References}

Abdullah, M., Kalam, A., Akterujjaman, S. J. I. J. o. H., \& Volume, M. S. (2013). Packaging factors determining consumer buying decision. 1 .

Ahmad, N., Billoo, M., \& Lakhan, A. A. J. J. o. b. s. (2012). Effect of product packaging in consumer buying decision. 6(2), 1-10.

Alrousan, R. M., \& Abuamoud, I. M. (2013). The mediation of tourists satisfaction on the relationship between tourism service quality and tourists loyalty: Five stars hotel in Jordanian environment. International Business Research, 6(8), 79.

Arens, W. F. (2002). Contemporary advertising: Tata McGraw-Hill Education. 
Asadollahi, A., \& Givee, M. J. C. M. R. (2011). The role of graphic design in packaging and sales of product in Iran. 1(5), 30-34.

Barclay, D., Higgins, C., \& Thompson, R. (1995). The partial least squares (PLS) approach to casual modeling: personal computer adoption ans use as an Illustration.

Chin, W. W. (1998). The partial least squares approach to structural equation modeling. Modern methods for business research, 295(2), 295-336.

De Faultrier, B., Towers, N. J. J. o. R., \& Services, C. (2011). An exploratory packaging study of the composite fashion footwear buying framework. 18(5), 463-470.

Fornell, C., \& Bookstein, F. L. (1982). Two structural equation models: LISREL and PLS applied to consumer exit-voice theory. Journal of Marketing research, 19(4), 440-452.

Fornell, C., \& Larcker, D. F. (1981). Evaluating structural equation models with unobservable variables and measurement error. Journal of Marketing research, 18(1), 39-50.

Gefen, D., Straub, D., \& Boudreau, M.-C. (2000). Structural equation modeling and regression: Guidelines for research practice. Communications of the association for information systems, 4(1), 7.

Ghosh, B. K. (2016). Impact of packaging on consumers' buying behaviour: a case study of Mother Dairy, Kolkata. Parikalpana: KIIT Journal of Management, 12(2), 27-34.

Gonzalez, M.-P., Thornsbury, S., \& Twede, D. J. J. o. f. d. R. (2007). Packaging as a tool for product development: Communicating value to consumers. 38(856-2016-57932), 61-66.

Hill, H., \& Tilley, J. J. B. F. J. (2002). Packaging of children's breakfast cereal: manufacturers versus children.

Keller, K. L., Parameswaran, M., \& Jacob, I. (2011). Strategic brand management: Building, measuring, and managing brand equity: Pearson Education India.

Kupiec, B., \& Revell, B. J. B. f. j. (2001). Measuring consumer quality judgements.

Lamb, C. W., Joseph F. Hair, J., \& McDaniel, C. (2004). Marketing (7th edition ed.). Canada: Thomson, southwestern.

Marsh, H. W., Hau, K.-T., \& Wen, Z. (2004). In search of golden rules: Comment on hypothesis-testing approaches to setting cutoff values for fit indexes and dangers in overgeneralizing Hu and Bentler's (1999) findings. Structural equation modeling, 11(3), 320-341.

Mutsikiwa, M., \& Marumbwa, J. J. I. J. B. M. (2013). The impact of aesthetics package design elements on consumer purchase decisions: a case of locally produced dairy products in Southern Zimbabwe. 8, 64-71.

Oaya, C. Z., Newman, O., \& Ezie, O. (2017). Impact of Packaging on Consumer Buying Behavior in Nasarawa State. International Journal of Sciences: Basic and Applied Research (IJSBAR) Vol, 36, 28-46.

Osman, Z., \& Sentosa, I. (2013). Mediating effect of customer satisfaction on service quality and customer loyalty relationship in Malaysian rural tourism. International Journal of Economics Business and Management Studies, 2(1), 25-37.

Osman, Z., Sentosa, I. J. I. J. o. E. B., \& Studies, M. (2013). Mediating effect of customer satisfaction on service quality and customer loyalty relationship in Malaysian rural tourism. 2(1), 25-37.

Raheem, A. R., Vishnu, P., \& Ahmed, A. M. J. E. j. o. s. r. (2014). Impact of product packaging on consumer's buying behavior. 122(2), 125-134.

Rettie, R., Brewer, C. J. J. o. p., \& management, b. (2000). The verbal and visual components of package design.

Rundh, B. (2005). The multi-faceted dimension of packaging. British food journal.

Rundh, B. J. B. f. j. (2005). The multi-faceted dimension of packaging.

Scholssberg, H. J. M. N. (2008). Effective packaging talks to consumers. 6.

Sehrawet, M., \& Kundu, S. C. (2007). Buying behaviour of rural and urban consumers in India: the impact of packaging. International Journal of Consumer Studies, 31(6), 630-638.

Sekaran, U., \& Bougie, R. (2010). Research Method of Business: A Skill Building Approach. John Willey \& Sons, New York, NY. In.

Shah, S., Ahmed, A., \& Ahmad, N. (2013). Role of packaging in consumer buying behavior. International Review of Basic and Applied Sciences, 1(2), 35-41.

Silayoi, P., \& Speece, M. J. B. f. j. (2004). Packaging and purchase decisions: An exploratory study on the impact of involvement level and time pressure. 106(8), 607-628.

Silayoi, P., \& Speece, M. J. E. j. o. m. (2007). The importance of packaging attributes: a conjoint analysis approach.

Smith, P. R., \& Walker, P. D. (2004). Packaging for pharmaceutical products. In: Google Patents.

Tse, A. C. B. J. E. j. o. m. (1999). Factors affecting consumer perceptions on product safety.

Twede, D. (2005). The Origins of Paper Based Packaging. Paper presented at the The Future of Marketing=s Past, Proceedings of the 12th Conference on Historical Analysis and Research in Marketing, ed. Leighann C. Neilson.

William, J. (1993). Fundamentals of marketing: Mcgraw-Hill Publishing Company. 